\title{
Leadership in Police Managers Training
}

\author{
Silvio Bratković \\ Lecturer \\ Police College, Ministry of the Interior \\ Croatia \\ Avenija G. Šuška 1 \\ Zagreb 10000 \\ Ksenija Butorac \\ Full Professor \\ Police College, Ministry of the Interior \\ Croatia \\ Avenija G. Šuška 1 \\ Zagreb 10000
}

\begin{abstract}
Leadership is one of the most important basic management functions and one of the most important tools for managers. This is especially true for police work. This paper gives an overview of relevant theoretical approaches and research on management and leadership. The importance of training of police managers in management and leadership is discussed in the light of recent insights into this area. Modern education and training standards are based on the European Qualifications Framework. Through learning outcomes, these standards ensure competencies required for performing the work of police managers. Through its recommendations and other documents, as well as through the work of agencies in charge of police training the EU provides support for development of its member states and in achieving common high standards. This paper examines possibilities provided by the EU in that regard and the manner of deliberation about the direction this development needs to take.
\end{abstract}

Keywords: management, leadership, leadership styles, European Qualification Framework, police managers training, competences

\section{Introduction}

Management is one of the most important human activities. This is a process of creating and maintaining an environment in which individuals, working together in a group, efficiently achieve specific objectives. Management consists of five basic functions - planning, organizing, staffing, directing and controlling (Koontz \& Weihrich, 1990). The mentioned definition of the term and functions of management is the most widespread one nowadays.

Throughout history, management was studied as an area by many authors. Roots of management as a discipline appear at the beginning of industrial revolution, more than 150 years ago (Drucker, 1974). The first decades of development were characterized by a great inconsistency in the development of individual elements that together began known as management, and at the beginning of the 20th century it became the subject of first scientific considerations (Taylor, 1947). More serious considerations of management as a function and as a discipline, and an area of study began only in mid-20th century, after WW2 (Drucker, 1974). This period resulted in first classifications of the principle and functions of management, and study of management as an economic category outside of business also began. The concept of management started being used in relation to any human activity that brought together people of different knowledge and skills in an organization. Management started being applied in other areas of human activities where strategies and goals were defined, that developed and trained people, measured their performance and effect and that promoted organizational services. On a world scale, management became a new social function (Drucker, 2001).

Henry Fayol (1949), who is considered to be the founder of management theory, provided us with the first known classification of management functions: planning, organizing, ordering, coordinating and controlling. Numerous authors gave their views of basic management functions, and in the last decades leadership has been listed among them as one of the most important ones. Many authors began simultaneously studying correlation of management and leadership on a theoretical level. 
They defined management as a process of steering others towards the execution of a particular task or organizational goal, and leadership puts an emphasis on the ability to influence others to perform a certain task (Robbins, 1997).

Managers do things right. Leaders do the right things (Drucker, 2001). Management is oriented towards achieving goals of organization, and leadership on guiding people in order to achieve the same goals. Management and leadership are two distinctive and complementary systems. Management deals with complexity, and leadership focuses on overcoming changes (Kotter, 1990). Leadership skills have now been universally recognized as a key ingredient in management (Adair, 2007).

The objective of this paper is to provide an overview of relevant theoretical approaches, styles and models of management and leadership that can be applied in the training of police managers.

\subsection{Theories, styles and models of leadership}

One of the first and most important authors dealing with leadership was Kurt Lewin (1951) who presented a theory on three basic leadership styles - autocratic or authoritarian - a leader who has clear expectations on what, when and how something should be done, and where the role of a leader and follower is clearly divided. The leader makes decisions independently, with very little influence from other group members; participative or democratic - leader leads the group but participates in work and allows active participation of other group members which motivates them, encourages them to participate but he still has the final word in making decisions; and delegating (laissez-faire) - his leadership does not influence group work much and leaves the decision-making to its members.

In the last fifty years or so, many theories were developed from which numerous styles or leadership models emerged. According to some theoretical discussions, there are three main approaches to leadership - the trait theory, the leadership style theory and situational or contingency theories (Handy, 1993). Others start from five perspectives of leadership necessary for a successful leader - person's traits, behavioral perspective, situational perspective, attributional perspective and substitutes for leadership (Gordon et al., 1990). But some authors list four main leadership theories - trait leader theory, behavioral leadership theory, contingency leadership theory and integrative leadership theory (Lussier \& Achua, 2004). There are many more theories with common elements, thus allowing us to talk about three basic approaches to theories - trait leadership based on the leader's traits, behavioral leadership based on the leader's behavior and the contingency or situational approach to leadership. Authors use other titles in their discussions - transactional leadership, relationship leadership, transformational leadership, but they can all be classified in one of the above-mentioned basic approaches.

Growing level of importance being attributed to leadership over a longer period of time has created certain myths about leadership as something almost superhuman and unreachable. Bennis and Nanus (1985) identified through research five generally accepted myths related to leadership and provided answers to them: Leadership is a rare skill (untrue - while great leaders may be rare, everyone has leadership potential); Leaders are born, not made (not so - major capacities and competencies of leadership can be learned and we can all learn it if we are motivated); Leaders are charismatic (some of them are, but most aren't); Leadership exists only at the top of the organization (the larger the organization is, the more Leadership role sit is likely to have); The leader controls and directs (not so - leadership is not so much the exercise of power, as it is the empowerment of the others, leaders lead by inspiring rather than ordering - by enabling people to use their own initiative and experiences) (Sadler, 2003; Northouse, 2010). Such answers to myths and the attitude that leadership is not preordained only for those who were "born" for it, but rather that different leadership styles operationalized into models can be taught, leaves space for training of, in this case, police managers.

Stogdill (as cited in Northouse, 2010) claims that there are almost as many different definitions of Leadership as there are people who have tried to define it. It is not possible to discuss all theoretical approaches, models and styles in this paper and thus the focus is aimed at certain styles or leadership models that are applicable and are used for training of police managers.

An extensive study conducted in 2011 under the NPIA ${ }^{1}$ covers all relevant UK and international research published in English with the goal to provide an overview of results in the area of leadership styles, behavior and competences and to give an answer to a key question - What makes a great police leader? 23 studies were studied in total in the period from 1979 - 2008. Most of the research were focused on the leaders' impact on subordinates and subordinates' perception of effectiveness of their leaders. Key findings suggest that there are some leadership styles that are more effective for police leadership then others:

\footnotetext{
${ }^{1}$ NPIA - National Policing Improvement Agency, United Kingdom
} 
Situational Leadership is the most effective style of leadership because leaders modify their behaviors to suit the context, including the years of experience, rank and role of their subordinates; Transformational Leadership is also effective because police leaders who are using that style have a positive impact on subordinates' organizational commitment and their willingness to exert extra effort and comply with directives; leaders who are using Transactional Leadership style that rely heavily on rewards and punishments may have fewer positive impact on subordinates, but in specific circumstances, when dealing with poor standards and performance of subordinates and for lower ranking and less experienced officers it can be also seen as effective style of leadership. Generally, the studies stress the value of transformational leadership behaviors, but above all, they point to the importance of being able to adapt style to suit context and this, sometimes, includes being able to provide directive, active leadership when required. (Campbell \& Kodz, 2011, p. 3-4, 21).

When talking about traits or characteristics of police managers, the results of a study done by Butorac, Orlović \& Žebec (2016) in the Republic of Croatia turned out to be quite interesting. The study looked at the opinion of police officers on the characteristics and skills of their managers / leaders by using the theory of three basic groups of knowledge and skills relevant to successful management - technical/professional, social and strategic skills (Katz, 1974). Research has shown that respondents are not satisfied with co-operation, manager support of associates, there is a lack of feedback and communication and taking responsibility for the benefit of staff/associates. Respondents also stated that such a situation has a negative impact on the organization, making it ineffective and long-term limiting to the development of the organization and the individuals in it. In connection with this, they believe that the commitment to the organization should be strengthened through the support of the associates, giving feedback, promoting co-operation and giving greater importance to associates in decision-making. One of the authors' conclusions is that such results imply certain changes in the training of Croatian police managers.

\section{Training of Police Managers}

When discussing any type of training curriculum within the context of contemporary tendencies in education, it is necessary to refer to the European Qualifications Framework. The European Qualifications Framework (EQF) is a common European reference framework whose purpose is to make qualifications more understandable across various countries and educational systems. It covers qualifications at all levels and in all sub-systems of education and training. This way, it connects national qualification systems (each member state has its own national qualification framework which represents the implementation of the EQF). EQF includes eight reference levels of qualifications defined through learning outcomes that express what the person knows, understands and can do at the end of the learning process (CEDEFOP, 2019). ${ }^{2}$ The mission of EQF is to contribute to the modernization of education and training systems, better interconnection of education, training and employability, and bridging the gap between formal, non-formal and informal learning. It also leads towards the recognition of learning outcomes gained through the experience of individuals.

Learning outcomes, knowledge, skills and competences are defined in EQF as: "Learning outcomes" means statements of what a learner knows, understands and is able to do on completion of a learning process, which are defined in terms of knowledge, skills and competences; 'knowledge' means the outcome of the assimilation of information through learning; 'skills' means the ability to apply knowledge and use know-how to complete tasks and solve problems and are described as cognitive (involving the use of logical, intuitive and creative thinking) or practical (involving manual dexterity and the use of methods, materials, tools and instruments) and 'competence' means the proven ability to use knowledge, skills and personal, social and/or methodological abilities, in work or study situations and in professional and personal development. In the context of the European Qualifications Framework, competence is described in terms of responsibility and autonomy (EU Parliament and Council, 2008). Recommendation on key competences for lifelong learning that defines $8 \mathrm{key}$ competences that all individuals need for personal fulfilment and development, active citizenship, social inclusion and employment (EU Parliament and Council, 2006) has also been adopted.

Police education systems of EU member states are a part of national education systems. They are complex education systems based on lifelong learning principles, i.e. on acquiring knowledge, skills and abilities needed for performing police work during the course of career. There is no prescribed organization and quality standard in the area of police education and training on the EU level, only specific recommendations provided in various documents and through exchange of experience between member states by using the good EU practice.

\footnotetext{
${ }^{2}$ CEDEFOP - European Centre for the Development of Vocational Training: European Qualification Frameworks (EQF).
} Retrieved from: http://www.cedefop.europa.eu/hr/events-and-projects/projects/european-qualifications-framework-eqf 
One of the most important documents in that regard is the Law Enforcement Training Scheme (CEPOL, 2012) developed by CEPOL. ${ }^{3}$ In accordance with the aforementioned document, every member state should have four areas of police training organized: basic police training and training for advancement in police service, bilateral and regional training, specialized training and external training (training for participation in third country missions).

CEPOL task is to organize different types of training - courses and seminars that take place in one of police education institutions of the EU member states (residential activities); learning via the Internet by using CEPOL on-line platform (webinars, on-line courses and on-line modules); exchange program (gaining experience in one of the EU member states) and joint programs through CEPOL common curriculum (CEPOL Common Curricula) - includes police training programs from different areas or topics with an European aspect. Higher education police education is also organized at CEPOL via program of joint study (CEPOL European Joint Master Program). This agency also promotes police science by organizing research and scientific conferences and by issuing publications (i.e. European Law Enforcement Research Bulletin) containing works of experts worldwide.

FRONTEX (from French - frontières extérieures - external borders) is an Agency for European border and coast guard founded in 2004. It has been functioning in its current form since 2016. This agency is responsible for coordinating activities of national border services related to surveillance of the EU external borders with its HQ in Warsaw. An important part of FRONTEX activities refers to providing assistance to the EU member states in the area of training of national organizations in charge of border surveillance (border police, border guard and coast guard). Educational activities of this agency are manifested through the establishment of common standards of training related to the surveillance of the state border (with the emphasis on monitoring the EU external borders), which is why the Sectoral Qualification Framework for Border Guarding (SQF) was designed. This is the key document supporting development of national systems and integration of all joint programs. It was developed in accordance with the EQF and within the framework of the individual qualification levels within which it elaborates all the required knowledge, skills and abilities, thus ensuring comparability of qualifications on the EU level. A common core of curricula and programs for basic training (Common Core Curriculum for Border Guard Basic Training - CCC Basic) was designed, as well as for training of mid-level border police managers (Common Core Curriculum for EU Mid-Level Border Guards - CCC Mid-Level). For the purpose of higher education in the border area, a common programming core was developed (Common Core Curriculum for High-Level Education and Training) based on which (by following the aforementioned SQF) a program was developed and a study was organized - European Joint Master's in Strategic Border Management. Besides the aforementioned, FRONTEX organizes the implementation of a variety of different courses and seminars for participants from the EU member states through the activities of its Training Unit, where the on-line platform plays an important role (FRONTEX Virtual Aula) as an Internet support for program implementation. Through the work of its agencies (apart from CEPOL and FRONTEX, there are also EASO, EIGE, eu-LISA, EUROJUST, EUROPOL4 and others), of which the two previously presented agencies are certainly the most important for training police and other bodies or organizations in charge of law enforcement, the European Union invests a lot of effort and provides great assistance to member states and to raising the level of their education systems and equalizing them within the European framework, thus strongly promoting the lifelong education of police officers.

In accordance with curricular theories and postulates, the curriculum of police education and training can be defined as the comprehensiveness of educational processes aimed at the development of police officers and the acquisition of competencies necessary for carrying out their duties (Bratković, 2015), and training of police officers, i.e. training for promotion in the police service is certainly an important and indispensable part of the police education system of each member state of the European Union.

\subsection{Training of police managers in the context of management and leadership}

Police systems in all developed countries have horizontal and vertical complexity. Horizontal is manifested in a large number of different police specialities and jobs, and vertical is the consequence of hierarchical organization of the system at several levels. The system is based on police career advancement by gaining qualification levels and gaining seniority in police ranks. There are different divisions in the theory of management but the most used is the division into three main hierarchical levels (Kroon, 1995; Gill, 2006; Murugesan, 2012):

\footnotetext{
${ }^{3}$ CEPOL - EU Agency for Law Enforcement Training: Law Enforcement Training Scheme. Mapping of Law Enforcement

Training in the European Union. Final report (PDF file). Retrieved from: https://enet.cepol.europa.eu/fileadmin/documents/LETS/LETS_Final_Report.pdf

${ }^{4}$ EASO - European Asylum Support Office; EIGE - European Institute for Gender Equality; eu-LISA - European Union

Agency for the Operational Management of Large-Scale IT Systems in the Area of Freedom, Security and Justice;

EUROJUST - European Union Office for Judicial Cooperation; EUROPOL - European Police Office.
} 
- Top level management (or Strategic level)

- Middle level management (or Tactical level)

- First level management (or Operative level).

The fundamental task of the police education system at all its levels and in all its forms is to provide educational measures to meet all the needs related to acquiring the competences needed to carry out police tasks, regardless of the hierarchical level and police speciality, i.e. workplace. A special place in this system is the training of police managers as one of the most important performance factors of the police system.

The European Union, through its agencies responsible for training of police officers or law enforcement officers (CEPOL and FRONTEX), offers programs that are content - related to leadership. In the category: Leadership, Language and Train the trainers, police officers from the EU member states and all the others who have access to CEPOL programs can choose two of those programs related to leadership: the EU Law enforcement leadership development $\&$ future leaders Module 1 and Module 2. These are residential - type programs (contact training in one of the EU member states) and they are held in Finland (CEPOL, 2019).

FRONTEX, the agency in charge of, among other things, training border police, border guard and coast guard officers of the EU member states, offers even greater possibilities. Police officers (in this case the border police, border guard or coast guard, depending on the organizational capabilities of an EU member state) can apply for European Joint Master's in Strategic Border Management study program that, if successfully completed, results in a new qualification level (level 7, i.e. Master). It also provides knowledge necessary for a successful career continuation at higher levels of management in their organizations. FRONTEX also organizes training for mid-level border police and coast guard managers in the form of FRONTEX MLC course (FRONTEX, 2019). This course is organized in cooperation with partner police academies of FRONTEX (police academies of the EU member states that have a cooperation agreement with this agency). It is organized in several modules, and each of them is held in another partner police academy (contact weeks). The first and most important module of this program refers to management and practical leadership. This module is organized in three parts, in accordance with the latest teaching organization models. During the first part (independent learning week), by using FRONTEX Virtual Aula (distance learning by using MOODLE platform) participants learn about different theories from areas of management and leadership, finishing it by writing an essay on the topic - Personal view on Leadership which is then evaluated by the trainers. In the second part (contact week), they have a week-long training at one of the partner police academies with trainers from all over Europe, using practical teaching methods as much as possible in order to, after acquiring theoretical knowledge, to also obtain leadership skills necessary for performing tasks of mid-level managers. It is important to emphasize that special attention is given to situational leadership, i.e. Hersey-Blanchard model of situational leadership which is based on four developmental phases of associates and on models and manners of behavior of managers for each of those developmental phases (Hersey, Blanchard and Johnson, 2008). The third part (experiential week) refers to fulfilling certain practical tasks from the area of leadership in their organizations at their workplaces. They also have to write a final paper in which they need to sublime theoretical knowledge, knowledge and skills acquired during contact week and their own views of leadership, i.e. they need to provide arguments on the extent and on which part the aforementioned training will be useful for their future work as mid-level managers. After successfully finishing the first module, participants can continue attending MLC, i.e. they can start with the activities from module 2 of the program. ${ }^{5}$

In accordance with the recommendations in European Training Scheme (European Commission, 2013), every member state is required to have one of the forms of police training for service advancement. In the Republic of Croatia, management is represented in the Police College programs at the bachelor level in the "Police management" class and at the master level in the "Strategic management" class. In these classes, the students - future police managers learn about the basics of management, and part of the class also deals with leadership. Leadership is also represented in programs of continuous professional development of police managers. In the mid-level police managers training course, the first module deals with contents related to police management and the participants are introduced to basic styles of leadership, with a special focus on situational leadership that is considered the most appropriate for mid-level police managers.

${ }^{5}$ FRONTEX MLC Course Curriculum Documentation and FRONTEX MLC Module 1 Handbook and Descriptor - the coauthor of this paper was included in developments of the respective documents and has been participated in implementation of the FRONTEX MLC Course as a trainer since 2017. 
In the second part that is being prepared, leadership will be represented more in the form of practical lessons - exercises, role-playing and other, i.e., after acquiring theoretical knowledge in the first module, the second one will focus on skills acquisition specially related to situational leadership and its usage in everyday police manager practice. A similar situation is also present in the advancement program for mid-level police managers in the Republic of Slovenia.

\section{Conclusion}

When discussing police managers training and having in mind theoretical deliberations and results of various research studies, leadership is definitely one of the most important topics. Therefore, it should be included in all training levels and programs, particularly in the training of first and middle level managers (Koontz \& Weihrich, 2010). Along with expert knowledge and experience, leadership skills represent the most important tools in everyday work of police managers. It should be noted that research, although there aren't many studies done in police management and leadership areas, has corroborated the importance and the necessity of training of police managers, primarily in the area of acquiring leadership skills. This research has also underpinned theoretical postulates in the areas of management and leadership and has pointed to the fact that, although the police is a hierarchical organization with a robust hierarchical division, it needs to develop modern forms of management and police managers should learn modern skills of leadership. This is because in the police, as in other organizations, satisfied and motivated employees deliver better results and possess a significantly stronger sense of belonging to an organization. The European Union offers numerous programs and possibilities for training in leadership to member states' police managers. Additionally, it provides training standards in the sense of organization, content and methods through its various documents and recommendations in that area. The Republic of Croatia is still, as the youngest EU member state, on the path of catching up to certain standards in that area. The police education system, its organization and particular components, i.e. sub-systems, are tailored to the level of standards of other member states. Although important development steps are being made in this area, there is still significant space for development in the area of training of police managers. These development directions need to follow the path of the most developed member states that practice the highest standards of police managers training, as well as follow CEPOL and FRONTEX recommendations, the two most important European agencies in the area of police training. Such orientation will indubitably result in a higher level of compliance and standardization of police education and in solid results in the development process. It will be useful to police managers and police organization, and subsequently to citizens in the form of a more efficient police organization and a higher level and sense of security.

\section{Reference List:}

Adair, J. (2007). Develop Your Leadership Skills. London and Philadelphia: Kogan Page.

Bratković, S. (2015). Kurikulumski kontekst strukovnog policijskog obrazovanja. Pedagogijska istraživanja, 12(1-2), 133-146.

Campbell, I., \& Kodz, J. (2011). What makes great police leadersip? United Kingdom: National Policing Improvement Agency,. Retrieved from: https://pdfs.semanticscholar.org/991b/dfe1face0f2f7674048ccc11f17c64613e4d.pdf

CEDEFOP (2019). European Qualification Frameworks (EQF). Retrieved from: http://www.cedefop.europa.eu/hr/events-and-projects/projects/european-qualifications-framework-eqf

CEPOL (2019). Education and Training. Retrieved from: https://www.cepol.europa.eu/education-training/what-weteach

CEPOL (2012). Law Enforcement Training Scheme. Mapping of Law Enforcement Training in the European Union. Final report (PDF file). Retrieved from:

https://enet.cepol.europa.eu/fileadmin/documents/LETS/LETS_Final_Report.pdf

Drucker, P. (2001). The Essential Drucker. London: Routledge

Drucker, P. (1974). Management. London: Routledge.

European Commission (2013). European Training Scheme. Brussels. Retrieved from: https://eurlex.europa.eu/LexUriServ/LexUriServ.do?uri=COM:2013:0172:FIN:EN:PDF

European Parliament and Council (2008). Recommendation of the Eruopean Parliament and of the Council on the establishment of the European Qualifications Framework for lifelong learning. Retrieved from: https://eurlex.europa.eu/LexUriServ/LexUriServ.do?uri=OJ:C:2008:111:0001:0007:EN:PDF

European Parliament and Council (2006). Recommendation of the European Parliament and of the Council of 18 December 2006 on key competences for lifelong learning. Official Journal of the European Union (2006/962/EC). Retrieved from: https://eur-lex.europa.eu/legal-content/EN/TXT/PDF/?uri=CELEX:32006H0962\&from=EN

FRONTEX (2019). Courses. Retrieved from: https://aula.frontex.europa.eu/courses/ 
FRONTEX (2018). MLC Module 1 Handbook and Descriptor. Internal document.

FRONTEX (2018). MLC Course Curriculum Documentation. Internal document.

Fayol, H. (1949). General and Industrial Management. London: Pitman.

Gill, R. (2006). Theory and Practice of Leadership. London: SAGE Publications, Ltd.

Gordon, J. R., Mondy, R. W., Shraplin, A., \& Premeaux, S. R. (1990). Management and Organizational Behaviour. Boston, MA: Allyn \& Bacon.

Handy, C. B. (1993). Understanding organizations (3rd ed.). London: Penguin Books

Hersey, P. H., Blanchard, K. H., \& Johnson, D. E. (2008). Management of Organizational Behavior: Leading Human Resources. Pearson Prentice Hall.

Katz, R. L. (1974). Skills of an effective administrator. Harvard Business Review, 52(5), 90-102.

Koontz, H., \& Weichrich, H. (2010). Essentials of Management. (8th ed.). New Delhi: Tata McGraw Hill Education Private Limited.

Kotter, J. P. (1990). What Leaders realy do?. Harvard Bussiness Review, 68 (2), 103-104.

Kroon, J. (1995). General Management (2nd ed.). Cape Town: Kagiso Tretiary.

Lewin, K. (1951). Field Theory in Social Science. USA: Harper \& Brother. Retrieved from: https://archive.org/details/in.ernet.dli.2015.138989

Lussier, R. N., \& Achua, C. F. (2005). Leadership - Theory, Application, Skill Development (2nd ed.). Mason, OH, Southwestern.

Murugesan, G. (2012). Principles of Management. New Delhi: University Science Press.

Northouse, P. G. (2010). Leadership: Theory and Practice (5th ed.). Los Angeles, London, Singapore, New Delhi, Washington: SAGE Publications, Inc.

Robbins, S. P. (1997). Essentials of Organizational Behaviour (5th ed.). Upper Saddle River, New York, Prentice Hall Sadler, P. (2003). Leadership. London, Sterling: Kogan Page Limited.

Taylor, F. W. (1947). The Scientific Management. New York, London: Harper\&Brothers Publishers. 